\title{
TABLES, FIGURES, MAPS, AND APPENDICES
}

\section{Tables}

1.1 Main Games of Christian Democratic Parties in This Volume 22

2.1 Deputies' Attitudes About Religious and Moral Issues 40

2.2 Citizen Attitudes About Religious and Moral Issues 41

2.3 Deputies' Attitudes About Social Spending 43

2.4 Christian Democratic Voter Attitudes About Social Equality 44

2.5 Deputies' Attitudes About the State's Role in Economic Development 45

2.6 Deputies' Attitudes About Privatization 46

2.7 Citizen Attitudes About Economic Liberalism, by Vote Preference: Chile, Mexico, and Venezuela 47

2.8 Position on Left-Right Scale, Christian Democratic Deputies 50

2.9 Mean Left-Right Location of Party Supporters: Chile, Mexico, and Venezuela 52

4.1 Christian Democratic Parties in Latin America 81

4.2 Results of Duration Analysis of Urbanization and Party Formation 82

4.3 Church Strength and Party Formation 83

4.4 Data for Duration Analysis 94

4.5 Results of Weibull Regression 100

4.6 Expected Times and Expected Time Ratios 101

4.7 Results of Exponential Regression 102

5.1 Self-Positions of Chileans on a Left-to-Right Scale, 1991-2001 124

5.2 Results of Elections for the Chamber of Deputies, 1925-1973 132

5.3 Percentage of Vote Earned by Deputies in 1989, 1993, 1997, and 2001, by Party 144 
5.4 Christian Democratic Vote Intention, 1990-2001, by Age 146

6.1 With What Political Position Do You Most Identify? 167

6.2 Ideological Distribution of the Chilean Electorate, 1958-1986 182

6.3 Left-Right Political Location of Party Identifiers, December 1997-January 1998183

7.1 Vote Distribution in the Election of Federal Deputies 203

7.2 Vote Distribution in the Election of Senators, 1964-2000 204

7.3 States with Significant PAN Participation in Federal Elections, 1961-2000 230

8.1 Political Issues and Democracy Index 255

8.2 Religious Attitudes 261

8.3 Mean Position of Party Supporters on Various Moral Issues and Liberal-Conservative Index 262

8.4 Model of Party Ideologies 263

8.5 Predicted Probabilities of Party Support 264

8.6 Bases of Support for Presidential Candidates: Mexico $2000 \quad 268$

9.1 COPEI Electoral Performance in National Elections, 1947-2000 283

9.2 COPEI Performance in Gubernatorial Elections 292

10.1 El Salvador: Election Results by Party, 1982-1999 311

10.2 Guatemala: Election Results by Party, 1984-1999 320

\section{Figures}

1.1 Spatial Electoral Competition with a Military Veto, I 13

1.2 Spatial Electoral Competition with a Military Veto, II 14

1.3 Spatial Electoral Competition with a Military Veto, III 15

7.1 Opposition Results in Presidential Elections, 1952-2000 202

8.1 Municipalities Controlled by PAN and PRD 250

8.2 Mean Position of Party Supporters on Various Economic Issues

8.3 Distribution of PAN Supporters on Economic and Moral Issue Dimensions 266

8.4 Distribution of PRD Supporters on Economic and Moral Issue Dimensions 266

8.5 Distribution of PRI Supporters on Economic and Moral Issue Dimensions 267

10.1 PDC's Percentage of Total Seats in Constituent Assembly/Legislature, $1982-2000 \quad 314$

10.2 DCG's Percentage of Total Seats in Constituent Assembly/Congress, 1984-1999 323 


\section{Maps}

8.1 Support for the PAN (1961 Federal Deputy Elections) 251

8.2 Support for the PAN (1970 Federal Deputy Elections) 251

8.3 Support for the PAN (1982 Federal Deputy Elections) 252

8.4 Support for the PAN (1997 Federal Deputy Elections) 253

\section{Appendices}

2A Electoral Results of Christian Democratic Parties in Latin America 56 4A The Use of Duration Analysis 111 
